\title{
E-marketing Practice in Bangladesh: An Empirical Study on Trend of Use and Expansion in Business
}

\begin{abstract}
Md. Abu Issa Gazi*
Department of Business Administration, The International University of Scholars, Middle Badda, Dhaka-1212, Bangladesh. *Correspondence: maigazi@yahoo.com (Dr. Md. Abu Issa Gazi, Assistant Professor, Dept. of Business Administration, IUS, Bangladesh)
\end{abstract}

\begin{abstract}
E-Marketing is considered to be a process of exploring, creating, and delivering value to satisfy the needs and wants of a target market at a profit electronically. The widespread use of the internet has had an effect on many traditional marketing in Bangladesh, by prompting levels of competition amongst businesses and changing established marketing structures. This paper addresses the intension of the use of E-marketing strategies in business in Bangladesh. A total 100 business owners was selected on random sampling basis from Dhaka city in Bangladesh. A structured questionnaire was used to collect the required data. In analyzing data descriptive statistics were applied. The author has studied the published data to conceptualize current scene of e-marketing progress in Bangladesh. They gathered data and information by using primary and secondary method. The study shows that in Bangladesh a praiseworthy rate of business owners have attained in online marketing and operating E-marketing tools for attracting qualified potential customers. The results also indicate that the policy implication to improve overall e-marketing and future prospects in the arena of E-marketing in Bangladesh. By developing and implementing E-marketing tools and techniques in business sectors in Bangladesh can take part to implementation of the dream of digital Bangladesh.
\end{abstract}

Keywords: Marketing, E-marketing, E-commerce, Information technology, Digital, and Information systems.

\section{INTRODUCTION:}

E-marketing plays a major and significant role in today's global economy, and is recognized as one of the prime contributor to economic, development and employment growth (Abrar et al., 2016). On the other hand, the revolution in information technology (IT) and communications changed the way people conduct business today. With passing of time, there is change of power which has been shifted from organizations to consumers (Hennig-Thurau et al., 2010; Hazlett, 2013). In modern era, internet applications are proficient and astounding weapon in business (Martins et al., 2014). Companies are investing huge money to

UniversePG I www.universepg.com implement and expand network and Internet technology (Gubbi et al., 2013). Waghmare (2012) pointed out that many countries in Asia are taking advantage of e-commerce and e-marketing through opening up, more than 2200 million internet users in Asia estimated in June-2019 (Internet World Stats, 2020; Zia and Manish, 2012). As almost all organizations have officially budged from traditional to internet environment (Taherdoost et al., 2015). By using cybernetic networks, numerous organizations have moved their marketing activities and operational activities on internet (Moss et al., 2013). Most of the Organizations are looking at the fresh open doors that are capable of maintaining strong partnerships with 
clients to create products by using online systems efficiently (Shih et al., 2013).

Gurau (2008) stated, social network marketing practitioners, online marketing is a constant opportunity for the market environment and challenges. Cyber space is an ideal playground for every type of organization regardless of its size (Anderson and Anderson, 2019). Bangladesh is not out of modern technology. The government of Bangladesh is trying to implement one of their major political agenda that is technological advancement in every socio-economic sector as a slogan the "Digital Bangladesh." But in regard to implementation of the dreams of Digital Bangladesh, the country's efforts are only at the beginning stages. Its current status falls short of standard in every constituent of e-government i.e. web initiatives, online services, infrastructure, and citizen's preparedness. It may be years before emarketing realizes its full potential in Bangladesh (Gilmore et al., 2007). In 1996 at June online facilities was ensured by the government. In the early 2000s, Bangladesh had 60,000 internet networks. In 1996, intercity fiber was connected together through optical network (Ali et al., 2016).

Bangladesh connected to the International Submarine Fiber Optical Network for the first time on November 22, 2005 (Shahidul, 2010). In 2006 Bangladesh Joined the Global Information Superhighway (SEA-ME-WE4) Submarine Cable Connection. Internet revolution is a recent phenomenon in Bangladesh. Bangladesh is now fully connected with the Internet revolution (Anower, 2012). As an internet user country the position of Bangladesh is $9^{\text {th }}$ around the world (Internet World Stats, 2020). This revolution also stirred many Small \& Medium Sized Enterprises (SMEs) in Bangladesh, especially those who are related to international business (Hamid, 2012). With the rise of this revolution, we are steadily getting used to the internet cultures. Almost every large scale companies, universities, news media, etc. have their respective sites. The total number of Internet Subscribers has reached 99.428 Million at the end of December, 2019 (BTRC, 2020). In 2019 households that have access to the internet by any device from home was increased $37.6 \%$ and percentage of women age 15-49 years who used the internet was increased 24.4 (BBS, 2019). UniversePG I www.universepg.com
However consider e-marketing in the country, identifying and analyze the basic premises of emarketing to help the potential business leader revitalize their business with e-marketing, implication and challenges to develop e-marketing (Ahmed et al., 2002). From the very beginning in Bangladesh, implementing E-Marketing in business enterprise can change both the shape and nature of its business and using as a new marketing phenomenon (Price et al., 2015). It is observed that despite of the fast growth in E-Marketing research in the last decade in Bangladesh, it appears that only last ten years researches on EMarketing and Internet Marketing begun to appear in Bangladesh. The interactive marketing offers instantaneous entrance to major product information when the consumer needs it. It also frees communications between marketers and their customers from the limits of the traditional (Talha, 2011).

Entrance of Internet Bangladesh has brought many possibilities and that has also affected marketing as well as these changes have generated several new challenges for the marketing professionals (Karjaluoto et al., 2015). It is a new channel for communication which brings along new opportunities for marketing to all businesses and industries in Bangladesh. Choudhury (2019) observed that e-marketing can be the strongest way to manage marketing operations and promote e-marketing in Bangladeshi products due to the mammoth popularity and public dependence of the Internet. It may be years before e-marketing realizes its full potential in Bangladesh, a growing number of companies, operating in various industries in Bangladesh have been moving online with an increasing proportion of their revenues being generated there.

This new marketing frame work has determined the success and failure of many businesses. There are some technical problems for e-marketing in Bangladesh that are strongly create obstacles to flourish e-marketing which are as absence of appropriate system security, reliability, standards and communication protocols (Khan, 2016). We need overall perfect and pragmatic guidelines of emarketing so that we can structure it efficiently and effectively (Ahammad et al., 2007). 


\section{Review of Literature}

The researcher viewed a wide range of previous literatures that are distributed in different journals and books and in websites. E-marketing is a new idea castoff by modern businesses (Ali et al., 2015). Emarketing creates the potential opportunity for business (Ali et al., 2016). E-marketing reduces expenses for marketing activities (Hassan et al., 2010). The company gained a lion's share of market through internet presence (Ya-Ping, 2012). A very communal confab in the e-marketing literature is that disintermediation will be extensive and electronic markets will automatically reduce the need for brokers. Strauss and Frost (2001) defined "E-marketing as a way to upgrade, implement, and distribute the prices of products and services by using digital applications for business development and for gratification of persons and firms". Christensen and Tedlow (2000) has argued that the Web market can truly satisfy most of the four definite missions of retailers; presenting the right product at the right place at right price and at right time by reducing time barriers, middlemen functions and physical offerings. E-marketing can feasibly educate the consumers regarding significance of time and space friendly and facilitate the consumers for connecting to internet and other virtual networks to purchase products (Ya-Ping, 2012). Electronic Marketing (E-Marketing) can be observed as a new thinking and a modern business practice involved with the marketing of goods, services, information and ideas via the Internet and other electronic means (Hoges and Cecil, 2003; Strauss and Frost, 2001; Christensen and Tedlow, 2000; Pelt, 2006; James, 2007; Carter, 2009; Guoling, 2005 ; Makesh, 2013).

From the reviewed relevant literature, it can be noted that the definition of electronic marketing (emarketing) changes according to each author's perspective, background and property. Smith and Chaffey (2005) defined "Achieving marketing objectives through applying digital technologies and the trading of products and service over the Internet" (Baourakis et al., 2002). Furthermore, e-marketing is one of the most effective online marketing tools because its high response rates (Niall, 2000). Malhotra (2008) said that "e-marketing can remove barriers to communication with customers and employees created by geography, time zones and location that are creating a conflict business environment". El-Gohary (2010) stated that "Marketing (e-marketing) is defined as the most modern realistic involvement in products, services, information and ideas through internet and other electronic ways". According to Farhoomand and Lovelock (2001) "E-marketing is a well-planned online marketing strategy, computer arbitrated market where sellers and buyers can interact with each one to accomplish corporate roles such as marketing, sales, and products distribution". Strauss and Frost (2001) has argued that e-marketing very supportive to improve the proficiency level of conventional marketing tasks, and e-marketing technologies modified many strategies through addition of customer value or increasing organization's profits.

Dehkordi et al. (2012) describe that "E-marketing strategies connect existing utilities and connect to communication and data networks and build relationships with potential customers through communication in the Internet environment". Xiaoming (2010) defines that "e-marketing is not only including the professional works that the marketing department deals with in marketing operating, but also it needs the cooperation by the relating business department." The customers who ready and review information over websites, usually they are in very good locus to save extra time for good decision making on organization's part, and also to make better purchasing decisions for their own well-being (Hennig-Thurau et al., 2010). One very profitable and useful way need to identify which products and services can be marketed quickly, any time and from any place and the modern businesses are increasingly applying technology in its marketing activities. Near future marketing activities will depend on the Web and internet (Choudhury, 2019). It is the salient task of researchers to understand that to what extent emarketing is subduing the effect of market positioning on marketing competencies and find out and open the road for marketers who want to invest in e-marketing for their business.

\section{Objectives of the Study}

To understand the contemporary scenario of emarketing and business owners' observation towards 
online marketing in Bangladesh Consequently, the objectives of this research are as follows:

1. To examine the range of technological advancement in marketing in Bangladesh;

2. To illustrate and clarify the reason for developing e-marketing and what marketing tools are effective for marketing in Bangladesh;

3. To analyze the use of technology within the promotional activities and significance of emarketing in the field of business in Bangladesh;

4. Finally, to formulate suitable implications to implement efficacious e-marketing strategies and techniques.

\section{METHODOLOGY:}

The present study was conducted based on primary and secondary methods. On the basis of pre-structured questionnaires all the information has been collected through personal interviews from owner of the business organization. In some cases Likert's five point scales was used to measure the respondents opinion. Researcher collected data from Dhaka city as a research area that the capital city of Bangladesh. Side by side this paper was tried to build on the current body of knowledge in the field of E-Marketing by systematically reviewed articles and the past publications in the field of E-Marketing that are distributed international journals of marketing, emarketing books and web sites to conceptualize current scene of Bangladesh.

\section{DATA ANALYSIS AND RESULTS:}

The inclination of the business owner towards emarketing was the core focus of the study; a structured $\&$ closed ended questionnaire was prepared for them only. The respondents' views were taken on a number of common aspects relating to e-marketing practices of their respective business organization by using descriptive statistical tools. In the following pages, an attempt has been made to evaluate their views on these issues:

Table 1: Respondents' opinion towards the knowledge about the use of internet $(\mathrm{N}=100)$.

\begin{tabular}{|c|c|c|}
\hline Opinion & Frequency & Percent \\
\hline $\begin{array}{c}\text { Not knowledgeable } \\
\text { about }\end{array}$ & 4 & $4 \%$ \\
\hline $\begin{array}{c}\text { Somewhat } \\
\text { knowledgeable about }\end{array}$ & 17 & $17 \%$ \\
\hline Knowledgeable about & 29 & $29 \%$ \\
\hline $\begin{array}{c}\text { Very well } \\
\text { knowledgeable about }\end{array}$ & 50 & $50 \%$ \\
\hline Total & $\mathbf{1 0 0}$ & $\mathbf{1 0 0 \%}$ \\
\hline
\end{tabular}

Knowledge about the use of internet - Internet is a nutshell of our daily lives now. A large numbers of business activities especially marketing that can be done by using internet. It has supported and hastened new forms of business interactions through instant messaging, internet forums, and social networking. Bangladeshi business owners trying to use internet for the marketing of their business and trying to earn proper knowledge how to use internet. To understand whether respondents are accustomed with the use of Internet were queried about knowledge of use of internet. The table reveals that when respondents were

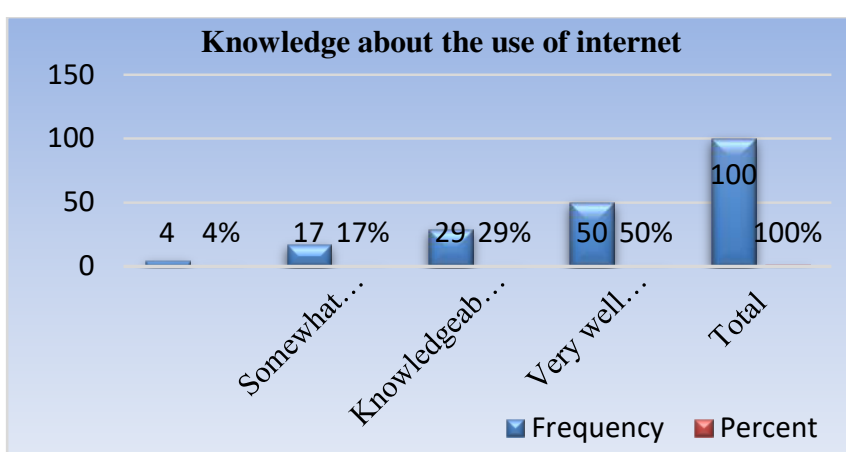

Fig 1: Respondents Knowledge about use of internet.

asked about their convergence with internet; $4 \%$ were not knowledgeable about internet, $17 \%$ were somewhat knowledgeable about internet, 29\% were knowledgeable about internet. 50\% were very well knowledgeable about internet. It observed that $50 \%$ respondents have very well knowledge about internet. They are well conversant with different usage, functions and benefits being offered by internet. While out of 100 respondents, only few i.e. $4 \%$ are not knowledgeable about internet. So it exposes that there is high degree of literacy for internet usage (Fig 1, and Table 1). 
From below table it is noted that within 100 respondents 48 percent business owners have their website of business that positively agreed that emarketing phenomena improve gradually, whereas 52 percent respondents don' have the website of their business. A notable percentage of respondents who were not introduce e-marketing strategy but most of the respondents think that website is need for business expansion as e-marketing strategy (Fig 2, and Table 2).

To analyze in detailed respondents were asked to give their view on customers have faith on website to get knowledge about their products and services. From table no. 2, it is observed that when respondents were first asked whether customers require much information to take purchase decision from their business website. And $41 \%$ respondents shown agree to and $59 \%$ respondents shown disagree. Thus majority of business owner think that customers have no faith on Website to get knowledge about their products and services to take purchase decision (Fig 3, and Table 3).

Table 2: Respondents' opinion towards the available of Website for their business organization $(\mathrm{N}=100)$.

\begin{tabular}{|c|c|c|}
\hline Opinion & Frequency & Percent \\
\hline Yes & 48 & $48 \%$ \\
& & \\
\hline No & 52 & $52 \%$ \\
\hline Total & $\mathbf{1 0 0}$ & $\mathbf{1 0 0 \%}$ \\
\hline
\end{tabular}

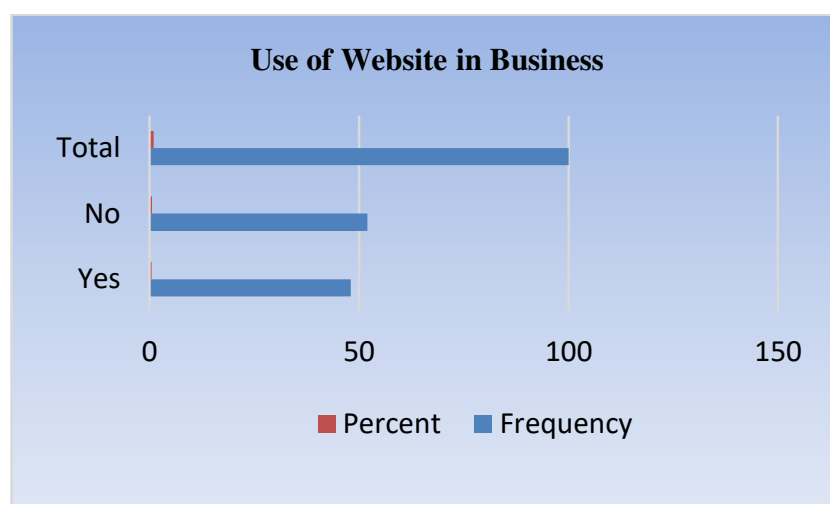

Fig 2: Respondents use of website in business.

Table 3: Respondents' opinion towards that customers have faith on Website to get knowledge about their products and services $(\mathrm{N}=100)$.

\begin{tabular}{|l|l|l|}
\hline Opinion & Frequency & Percent \\
\hline Yes & 41 & $41 \%$ \\
\hline No & 59 & $59 \%$ \\
\hline Total & $\mathbf{1 0 0}$ & $\mathbf{1 0 0 \%}$ \\
\hline
\end{tabular}

Respondents' opinion towards importance of EMarketing - E-Marketing denotes to a set of dominant tools and technologies use for promoting goods and services through the internet. It connects business UniversePG I www.universepg.com

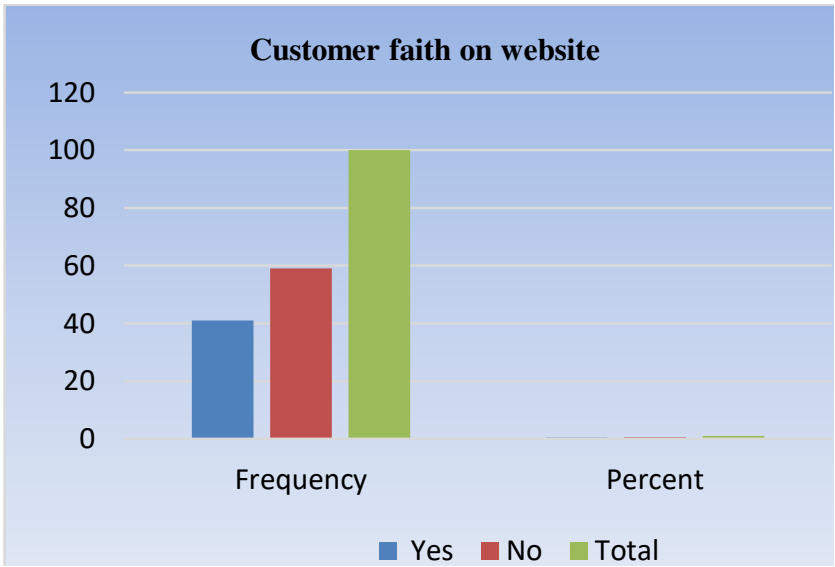

Fig 3: Customer faith on website to get knowledge.

organizations with prospective customers and possible high business development than traditional marketing. The study show up that on the importance of emarketing were strongly agree since more than 60 
percent business owners have shown a privileged level of agree, 21 percent owners have shown disagree and only 5 percent strongly disagree towards mentioned matter (Fig 4, and Table 4).

Use of E-marketing activities by business owner in their marketing efforts - Now days, potential customer trust more on internet's shared information, customers follow information for brand evaluation and for making buying decision. This scope must be grabbed by all businesses by having their online presence. For business organization online presence can be a technique that involves use of internet as a medium marketing strategy. On the basis of use of online activities as e-marketing tactic in their marketing strategy that have their business website (N-48) significant differences were observed. From table no. 4 , it is observed that among the user of website $68.75 \%$ (33) use internet e-marketing strategy. On the other hand $31.25 \%$ (15) user of website not uses internet e-marketing strategy. It means majority of respondents are completely agreed that business organization should use online activities in their marketing efforts (Fig 5, and Table 5).

\section{Respondents' opinion towards use of E-Marketing} tools most preferably - The success of E-Marketing rely on the extent of its establishment and accomplishment to achieve the anticipated outcomes.

Table 4: Respondents' opinion towards importance of E-Marketing $(\mathrm{N}=100)$.

\begin{tabular}{|c|c|c|}
\hline Opinion & Frequency & Percent \\
\hline Strongly disagree & 5 & $5 \%$ \\
\hline Disagree & 21 & $21 \%$ \\
\hline Strongly agree & 61 & $61 \%$ \\
\hline Agree & 13 & $13 \%$ \\
\hline No opinion & 0 & $0 \%$ \\
\hline Total & 100 & $\mathbf{1 0 0 \%}$ \\
\hline
\end{tabular}

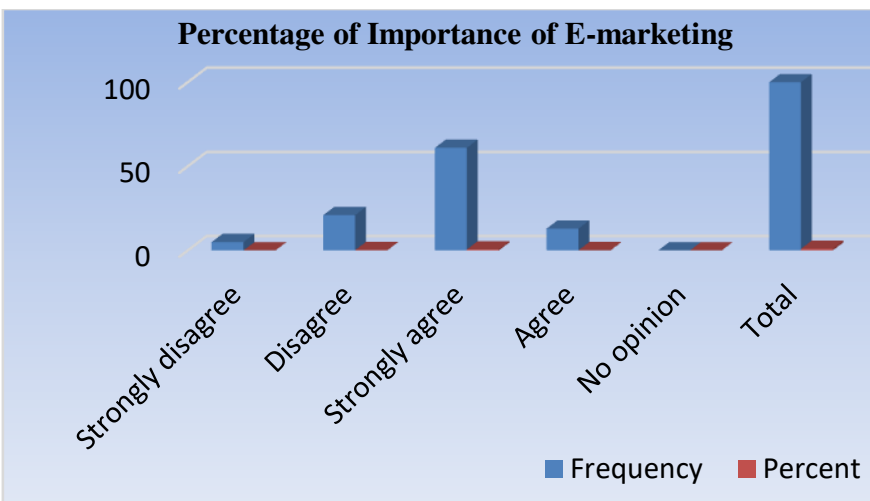

Fig 4: Percentage of importance of E-marketing.

Table 5: Respondents' opinion towards use of online activities as E-Marketing tactic in their marketing strategy who have their business website $(\mathrm{N}=48)$.

\begin{tabular}{|c|c|c|}
\hline Opinion & Frequency & Percent \\
\hline Yes & 33 & $68.75 \%$ \\
\hline No & 15 & $31.25 \%$ \\
\hline Total & $\mathbf{4 8}$ & $\mathbf{1 0 0 \%}$ \\
\hline
\end{tabular}

E-Marketing performance also depends strongly on its incessant assessment (Apriyanti, 2020). A significant number of business organizations in Bangladesh promote their products and services by demonstrating

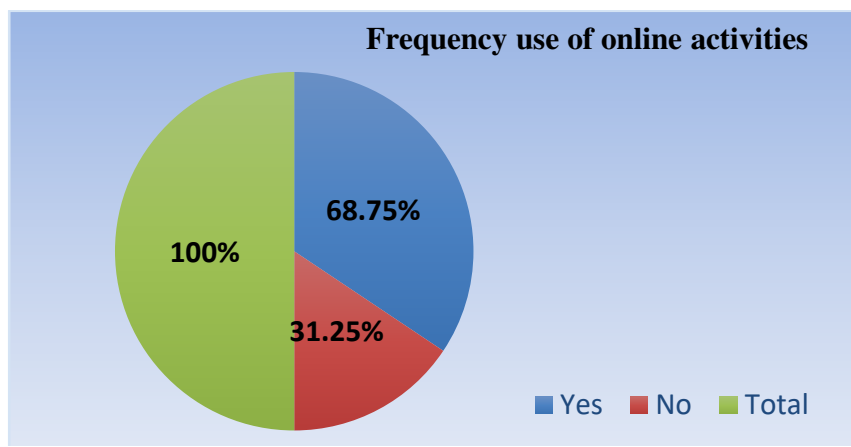

Fig 5: Frequency use of online activities.

E-marketing tools. Which tool most preferably use for e-marketing activities by Bangladeshi business owner were asked. From below table it is noted that within 100 respondents51 percent business organizations in 
Bangladesh positively use social media as an emarketing tool that means gradually improving emarketing practice, whereas 33 per cent respondents use their business website as an e-marketing tool. Only 9 percentage of respondents who are using email but most of the respondents think that without using of e-marketing strategy they couldn't survive. They express for getting the way out of perfect emarketing tool and not just to show their potency to the marketing management (Gazi, 2020). The respondents who stated their reluctance to take part in e-marketing policy the causes like panic of insecurity, indifference, lacking about the knowledge of emarketing and internet, etc (Fig 6, and Table 6).
Benefits of E-marketing over the traditional marketing - At present, e-marketing technologies logically tallying marketing methods to the traditional on. Traditional marketing merely is a comprehensive genus that combines various forms of advertising and marketing. But the enormous number of platforms that Internet creates. It offers definite benefits to customers over traditional marketing. The Internet is ubiquitous and incorporates every aspect of business promotion. E-marketing is perceived like a new business practice that flourishes the business arena to create a strong online presence. The respondents' views were taken on benefits of e-marketing over traditional marketing.

Table 6: Respondents' opinion towards use of E-Marketing tools most preferably N=100).

\begin{tabular}{|c|c|c|}
\hline Opinion & Frequency & Percent \\
\hline $\begin{array}{c}\text { Social Media } \\
\text { Marketing }\end{array}$ & 51 & $51 \%$ \\
\hline Content Marketing & 1 & $1 \%$ \\
\hline E-market place & 5 & $5 \%$ \\
\hline E-mail & 9 & $9 \%$ \\
\hline Website & 33 & $33 \%$ \\
\hline Sponsored link & 1 & $1 \%$ \\
\hline Total & $\mathbf{1 0 0}$ & $\mathbf{1 0 0 \%}$ \\
\hline
\end{tabular}

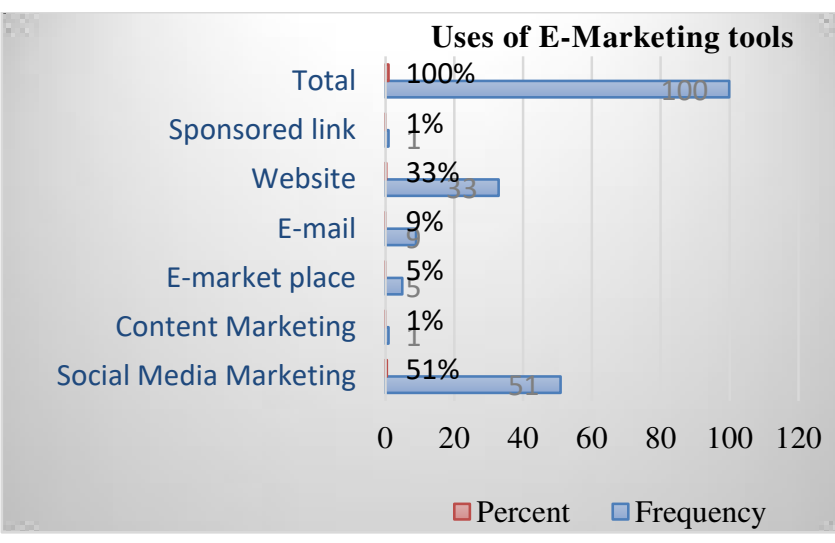

Fig 6: Uses of E-Marketing tools most preferably.

Table 7: Respondents' opinion towards Benefits of E-marketing over the traditional marketing (most likely) $(\mathrm{N}=100)$.

\begin{tabular}{|c|c|c|}
\hline Opinion & Frequency & Percent \\
\hline Low cost & 7 & $7 \%$ \\
\hline Time saving & 8 & $8 \%$ \\
\hline $\begin{array}{c}\text { Fast reach to } \\
\text { customer }\end{array}$ & 62 & $62 \%$ \\
\hline $\begin{array}{c}\text { Vast of } \\
\text { Information }\end{array}$ & 20 & $20 \%$ \\
\hline Long term use & 3 & $\mathbf{1 0 0 \%}$ \\
\hline Total & $\mathbf{1 0 0}$ & \multicolumn{2}{|c|}{} \\
\hline
\end{tabular}

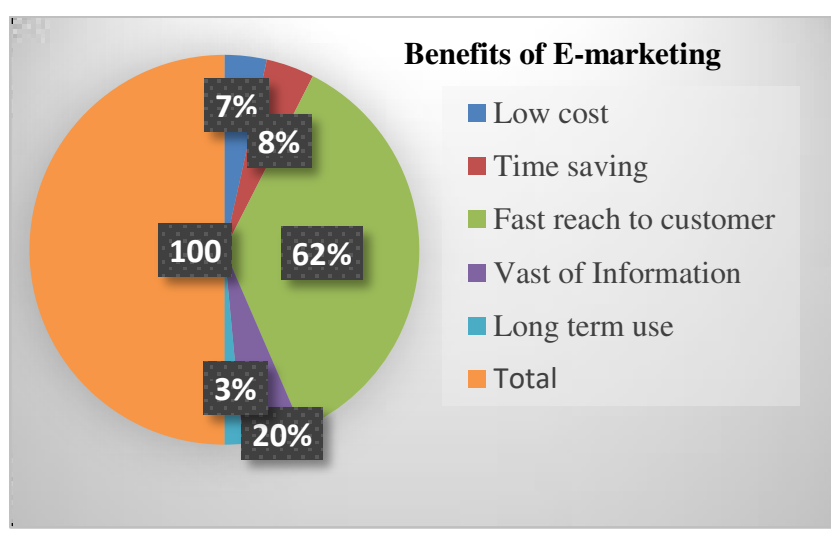

Fig 7: Opinion towards benefits of E-marketing.

During the survey it was observed that a majority of respondents acknowledge the benefits of online marketing over traditional marketing. The number of highest respondents grants its benefits as fast reach to UniversePG I www.universepg.com customer that is 72 percent. It is also observed that $20 \%$ of respondents find e-marketing advantageous as it offers wide range of information about the brand, $8 \%$ of respondents find e-marketing advantageous as it 
saves marketer and customer's time, $7 \%$ of respondents find e- marketing beneficial as it comprises low cost in advertising, only 3\% of respondents find online marketing convenient as it is long term use. It means majority of respondents favor for fast reach to customer (Fig 7, and Table 7).

Table 8: Respondents' opinion towards Limitations of E-Marketing ( $\mathrm{N}=100)$.

\begin{tabular}{|c|c|c|c|c|c|c|}
\hline \multirow{2}{*}{ Opinion } & \multicolumn{5}{|c|}{ Frequency (Percent) } & \multirow{2}{*}{ Mean } \\
\cline { 2 - 6 } & $\begin{array}{c}\text { Unwillingness } \\
\text { of customer }\end{array}$ & $\begin{array}{c}\text { Fraudulent } \\
\text { activities }\end{array}$ & $\begin{array}{c}\text { Lack of } \\
\text { Privacy }\end{array}$ & $\begin{array}{c}\text { More } \\
\text { Vulnerable }\end{array}$ & $\begin{array}{c}\text { Often } \\
\text { interrupting }\end{array}$ & \\
\hline Strongly disagree & $18 \%$ & $7 \%$ & $13 \%$ & $6 \%$ & $9 \%$ & $11 \%$ \\
\hline Disagree & $15 \%$ & $18 \%$ & $11 \%$ & $10 \%$ & $8 \%$ & $12 \%$ \\
\hline Strongly agree & $48 \%$ & $51 \%$ & $43 \%$ & $58 \%$ & $60 \%$ & $52 \%$ \\
\hline Agree & $19 \%$ & $23 \%$ & $33 \%$ & $26 \%$ & $22 \%$ & $25 \%$ \\
\hline No opinion & $0 \%$ & $1 \%$ & $0 \%$ & $0 \%$ & $1 \%$ & $0 \%$ \\
\hline Total & $\mathbf{1 0 0 \%}$ & $\mathbf{1 0 0 \%}$ & $\mathbf{1 0 0 \%}$ & $\mathbf{1 0 0 \%}$ & $\mathbf{1 0 0 \%}$ & $\mathbf{1 0 0 \%}$ \\
\hline
\end{tabular}

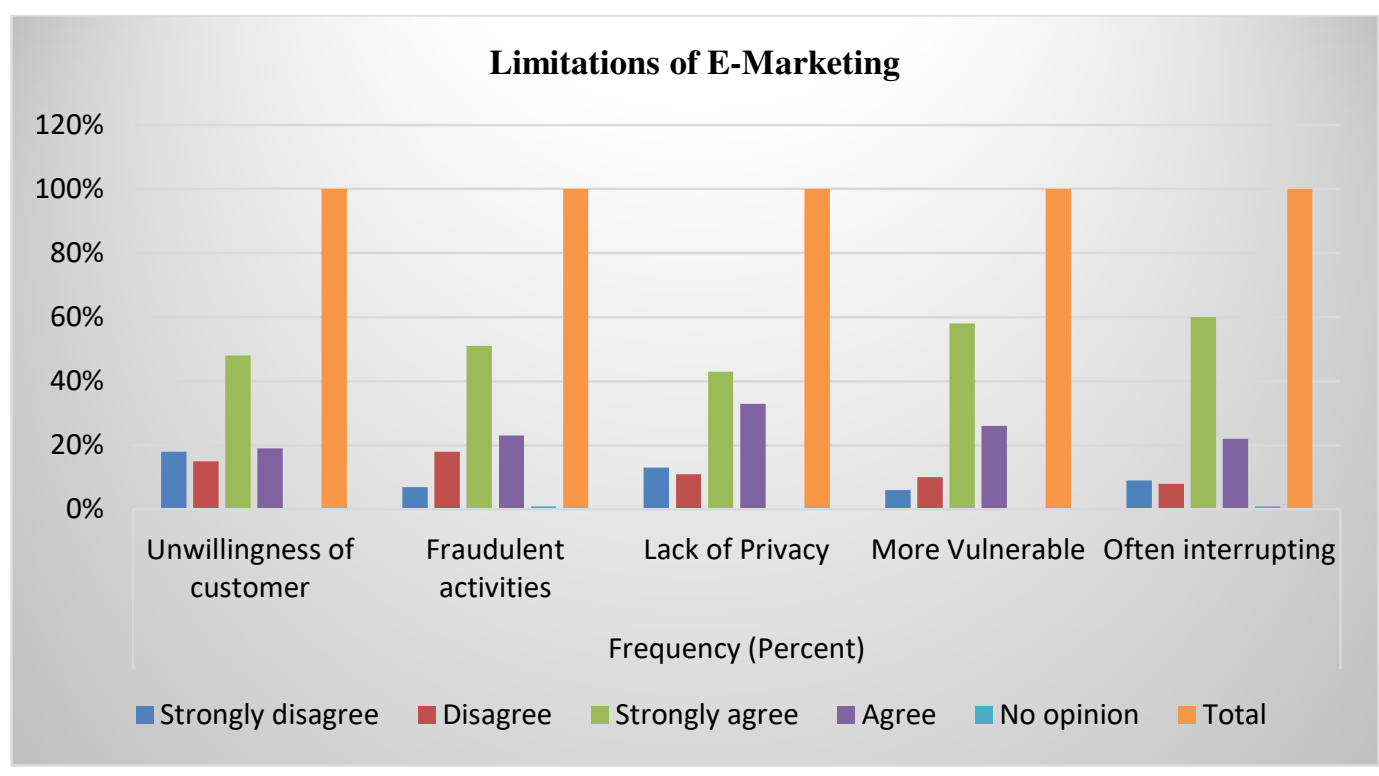

Fig 8: Respondents' opinion towards Limitations of E-Marketing.

Respondents' opinion towards Limitations of EMarketing - From the above graphical presentation and table no. 7 , it is observed that most of the respondents have scary concern about limitation of emarketing. Average 52 percent respondent seems and views strongly agree that several severe problems are available behind the e-marking strategy, $25 \%$ views agree about limitations of e-marketing. It is also observed that unwillingness of customer, respondents find e- marketing is not safe as there is more scope of fraudulent activities, lack of privacy, it is more vulnerable and often interrupting that are shows strongly agree of $48 \%, 51 \%, 43 \%, 58 \%$ and $60 \%$ respectively and reveals respondents agree of $19 \%$, $23 \%, 33 \%, 26 \%$ and $22 \%$ respectively. Besides, only average $12 \%$ disagree and $11 \%$ strongly disagree about the e-marketing limitations. That means few respondents opposed their views those who are favor of refraining online marketing activities as acknowledge some limitations of e-marketing (Fig 8, and Table 8).

\section{Key Findings of the Study}

E-marketing plays an important role to expansion of sales volume of any organization by online advertising, campaign, promoting and communication 
with quality potential customers. From the analysis of the present study we find the following findings:

1. The findings related the knowledge about internet that the number of respondent business owners is significantly higher with their internet know-how.

2. It is found that the number of respondent business owners is not significantly higher with their websites for e-marketing. Most portion of the business owner in Dhaka city not using website and internet for marketing.

3. It is seen from the discussion that among 100 respondents' 59 respondents believes emarketing strategy not effective as much as we think for buying decision of customers because customers rarely believe in online marketing and advertising in the current era of information scarcity.

4. It is found that while customers do not fully trust on the online information when it comes to purchasing decisions, merchants do not deny the importance of e-marketing. Most business owner strongly endorses the significance of emarketing.

5. The study showed up that there is significant difference between website users for emarketing strategy. Most of those who have their business websites want to reach out with information to potential customers about products and services as a strategy of emarketing.

6. The result exposed from the study that business owners prefer social media as an e-marketing tool. Since most of the respondents have sufficient knowledge of internet, for most of the online marketing activities they use as much as social media. On the other hand, as an e-marketing tool the number of website users is not less.

7. It is also seen from the study that the respondents are deeply concerned about the limitations of e-marketing. The limitations that were raised in front of them are not as pleasant as most of all. There are strong opinions that all the impediments are lagging behind emarketing development in Bangladesh.

\section{CONCLUSION AND RECOMMENDATIONS:}

The present study was an exertion to get hold of a better understanding about the trend of use and expansion of e-marketing in Bangladesh. E-marketing is accommodating to improve organization's marketing policy and has resilient effect on customers buying behavior and business markets. E-marketing is perceived like a new marketing strategy. The application of e-marketing in today's business has resulted as prerequisites for developing modern marketing practices. It is a very atonement that many large scale businesses organizations don't have a web site and not using e-marketing tools yet in Bangladesh. However the consciousness of use of e-marketing in business is still in its beginning stage in Bangladesh. Despite, problems by the use of e-marking increasing day by day. In the era of globalization we should step forward with fast changing technology and also should try to improve e-marketing structures while a new means of conducting business has become competitive advantages. Thus, from the findings and of reviewed literature of this study it is recommended that;

- It is seen from the study that most of the respondents have knowledge of internet. It is good sign but lack of depth of knowledge regarding internet and online marketing that's failing to bring success to the business. In order to assure the successful practice of emarketing in Bangladesh, get started with emarketing technology it is very important to learn some skills and know-how for launching e-marketing effectively. So need to arrange proper training and technological know-how methods to the concern peoples.

- The present study showed that most of the business organizations have no website of its own. There are many reasons behind it that need to be addressed and resolved. So, emarketing systems should be simple and complex free to use, high speed internet accessibility, interesting, time saving, appropriate infrastructure, fast and user friendly.

- The research has found that business owners think e-marketing is a poor way to attract consumers. Because the information provided 
online is low in trust customers. So, all parties need to take action to create a place of consumer's trust, especially the information provided online to be consistent, true and updated.

- By considering the importance of e-marketing, government should develop operative legal framework and implement the cyber laws to ensure proper privacy, security about marketers and customers' information.

- The obtained result from the study says that business people are only giving importance to social media as an e-marketing tool. However to gain and develop facilities of e-marketing it is necessary to ensure the full use of all such tools.

- According to research findings most respondents are unhappy about all of the backlogs of e-marketing. The mentioned problems need to be solved properly and effective action. Government and business association should take steps to make awareness of advantages of e-marketing. So, should organize marketing research program immediately and logistic support in this regard.

\section{ACKNOWLEDGEENT:}

First and foremost, I am grateful to Almighty Allah. I am really grateful to my beloved wife who inspired me for the completion of this hardship tasks as well as worship endeavors. I am also grateful to Professor Mossaraf Hossain Sarkar who taught me about research.

\section{CONFLICT OF INTERESTS:}

The author has no declaration of interest.

\section{REFERECES:}

1. Abrar M, Safeer AA, Baig SA, and Ghafoor A. (2016). E-Marketing and Its Implementation on Developing Social Perceptions of Customers through Effective Marketing Mix of Organic Textile Products. Amer. J. of Indust. and Busi. Manag., 6, 1194-1211. http://dx.doi.org/10.4236/ajibm.2016.612110
2. Ahammad A. (2007). Prospects of ecommerce in Bangladesh, Journal of Science and Technology, 5: 74-80.

3. Ahmed INA, Habib MW, and Khan MM. (2002). Electronic Commerce in the epoch of Information Technology: Its opportunities and Challenges in the Business Landscape of Bangladesh. J. of Business Studies, 23, 2.

4. Ali MM, Ahmed R, and Rahman A. (2016). Present Scenarios, Opportunities and Obstacles of e-business in Bangladesh, D.U. Journal of Marketing, 16(2), June 2016.

5. Ali Z, Ejaz S, and Aleem A. (2015). Understanding E-Marketing as a Firm's Promotional tool: It's Impact on Consumer Perception, International J. of Academic Research in Business and Social Sciences, 5, 3: 1-15. https://doi.org/10.6007/IJARBSS/v5-i3/1526

6. Anderson M, and Anderson M. (2019). Dissecting 'Subservient Chicken'. Retrieved 31 August 2019.

https://www.adweek.com/brand-marketing/ dissectingsubservientchicken-78190

7. Anower A. (2012). E-marketing, Social Science Electronic Publishing, Inc

8. Apriyanti HW. (2020). Measurement and assessment of the developmental status of Islamic University governance: Indonesia perspective, Int. J. Manag. Account. 2(1), 1021. https://doi.org/10.34104/ijma.020.10021

9. BBS (2019). Bangladesh Bureau of Statistics, Progotir Pathey, Bangladesh Multiple Indicator Cluster Survey 2019, Key Findings. Dhaka, Bangladesh: Bangladesh Bureau of Statistics (BBS).

10. Baourakis G, Kourgiantakis M, and Migdalas A. (2002). The impact of e-commerce on agro food marketing: the case of agricultural cooperatives, firms and consumers in Crete, British Food Journal, 104, 580-590.

11. BTRC (2020). http://www.btrc.gov.bd/content/ internet-subscribers-bangladesh-december-2019

12. Carter E. (2009). Mobile Marketing and Generation Y African-American Mobile Consumers: The Issue and Opportunities, Inter. J. of Mobile Marketing, 3(1), 62-66. 
13. Choudhury S. (2019). E-Marketing as an Opportunity to Expand Textile Sector of Bangladesh, Asian Journal of Management. 10(4): 305-311.

https://doi.org/10.5958/2321\%205763.2019.000 $\underline{45.3}$

14. Christensen, Clayton M, and Richard ST. (2000): "Patterns of Disruption in Retailing."

Harvard Business Review, 78(1): p 42.

15. Dehkordi JG. (2012). A Conceptual Study on E-marketing and Its Operation on Firm's Promotion and Understanding Customer's Response, Retrieved, March 10 2020.

http://dx.doi.org./10.5539/ijbm.v7n19p114

16. El-Gohary H. (2010). E-Marketing: A literature Review from a Small Businesses perspective, International Journal of Business and Social Science, 1(1), 214-244.

17. Farhoomand A F, and Lovelock P. (2001). Global E-Commerce: Text and Cases plus Instructor's Manual. Prentice-Hall, Upper Saddle River.

18. Faroqi M. Gofran A. (2008). E-Government in Bangladesh: Recent Progress and Future Challenges. Bangladesh J. of Public Administration, 17(2), 2008.

19. Gazi MAI. (2020). Islamic perspective of leadership in management; foundation, traits and principles, Int. J. Manag. Account. 2(1), 1-9.

https://doi.org/10.34104/ijma.020.0109

20. Gilmore A, Gallagher D, and Henry S. (2007). E-marketing and SMEs: Operational Lessons for the Future. Euro. Busi. Rev., 19, 234-247. https://doi.org/10.1108/09555340710746482

21. Gubbi J, Buyya R, Marusic S, and Palaniswami M. (2013). Internet of things (IoT): A Vision, Architectural Elements, and Future Directions. Future Generation Computer Systems, 29, 1645-1660. https://doi.org/10.1016/j.future.2013.01.010

22. Guoling L. (2005). Survey on Theory Developing of E-commerce in Past 10 Years, Software Guide, Peking, China, 14, 37-41.

23. Gurau C. (2008). Integrated online marketing communication: implementation and management, Journal of Communication Management, 12(2), 169-184

24. Hamid A. (2012). E-marketing in Bangladesh, Online Marketing Journal. https://www.researchgate.net/publication/22832 1495

25. Hassan M, Sultana (2010). “Online Marketing in Bangladesh: A Descriptive Study in the Context of Some Selected Click and Mortar Businesses", 5(2), July- December.

26. Hazlett K. (2013). Marketing to the Social Web: How Digital Customer Communities Build Your Business. Journal of Consumer Marketing, 27, 293 -295. https://doi.org/10.1108/07363761011038383

27. Hennig-Thurau T, Friege $\mathrm{C}$, Gensler S, Lobschat L, and Skiera B. (2010). The Impact of New Media on Customer Relationships. Journal of Service Research, 13, 311-330. https://doi.org/10.1177/1094670510375460

28. Hoges C, and Cecil Sr. (2003). Integrating Electronic Media into Your Marketing Present Scenarios, Opportunities and Obstacles of EBusiness in Bangladesh 21 Campaign, The Electronic Marketing Manual, Retrieved from http://http//:www.\%20google.com.archives.obsu s.com/obs/german/books/elecmanu/htm/

29. Internet World Stats (IWS). (2020). www.internetworldstats.com/

30. Islam MT, and Alam MJ. (2019). The relationship between informal economy and GDP growth: a study on south-asian developing countries. Can. J. Bus. Inf. Stud., 1(5), 01-09.

https://doi.org/10.34104/cjbis.019.0109

31. James D. (2007). Bid on Dream girls Costumes for Charity, People Magazine Time Inc., February 24.

32. Jony MTI, Alam MJ, and Alam MJ. (2019). The impact of autocratic, democratic and laissez-faire leadership styles on the success of the organization: a study on the different popular restaurants of Mymensingh, Bangladesh, Can. J. Bus. Inf. Stud., 1(6), 2838.

https://doi.org/10.34104/cjbis.019.028038 
33. Karjaluoto H, Mustonen N, and Ulkuniemi P. (2015). The Role of Digital Channels in Industrial Marketing Communications. J. of Business \& Industrial Marketing, 30,703-710. https://doi.org/10.1108/JBIM-04-2013-0092

34. Khan AG. (2016). Present Scenarios, Opportunities and Obstacles of E-Business in Bangladesh, Global Journal of Management and Business Research, 16(1), 1-5.

35. Makesh N. (2013). E-marketing - A New Concept. International Journal of scientific research and management (IJSRM). Pp 50-54.

36. Malhotra V. (2008). Best Place for Online marketing strategies, Article Source: http://www.articlesnatch.com/

37. Martins C, Oliveira T, and Popovic A. (2014). Understanding the Internet Banking Adoption: A Unified Theory of Acceptance and Use of Technology and Perceived Risk Application. Intern. J. of Infor. Management, 34, 1-13. https://doi.org/10.1016/j.ijinfomgt.2013.06.002

38. Moss GA, Wulf C, and Mullen H. (2013). Internet Marketing to 50+ Generations in the UK and France. Journal of International Consumer Marketing, 25, 45-58. https://doi.org/10.1080/08961530.2013.751799

39. Niall J. (2000). The Email Marketing Dialogue, Forrester, Cambridge: M. A.

40. Pelt JV. (2006). Online Marketing Heats up Holiday Retailing. Source of article. http://www.techweb.com/wire/ebiz/193104234

41. Price RA, Wrigley C, and Straker K. (2015). Not Just What They Want, but Why They Want It: Traditional Market Research to Deep Customer Insights. Qualitative Market Research: An International J, 18, 230-248.

42. Shahidul H. (2010). Information revolution of internet, Professors Publication, Bangladesh.

43. Shih B, Chen C, and Chen Z. (2013). An Empirical Study of an Internet Marketing
Strategy for Search Engine Optimization. Human Factors and Ergonomics in Manufacturing and Service Industries, 23(6), 528-540. https://doi.org/10.1002/hfm.20348

44. Shuvro RA, Saha S, and Alam MJ. (2020). Measuring the level of job satisfaction of the employees of Grameen bank: an empirical study, Can. J. Bus. Inf. Stud., 2(1), 1-11. https://doi.org/10.34104/cjbis.020.01011

45. Smith PR, and Chaffey D. (2005). EMarketing excellence: at the heart of eBusiness, $2^{\text {nd }}$ Edition Butterworth Heinemann, Oxford, UK. Oxford, UK, Butterworth Heinemann.

46. Strauss J, and Frost R. (2001). E-Marketing. Prentice-Hall, Upper Saddle River, NJ.

47. Taherdoost H, Sahibuddin S, and Jalaliyoon N. (2015). A Review Paper on E-Service; Technology Concepts. Procedia Technology, 19, 1067-1074.

https://doi.org/10.1016/j.protcy.2015.02.152

48. Talha M. (2004). Problems and Prospects of Internet Marketing, J. of International Business and Commerce, 9(1), 1-12.

49. Waghmare GT. (2012). E-commerce; A Business Review and Future Prospects in Indian Business. Internet Marketing in India. Indian Streams Research J., 2(4), 1-4.

50. Xiaoming M. (2010). E-commerce and Emarketing, Electronic Industry Press, Peking, China.

51. Ya-Ping H. (2012). E-Marketing Development in Virtual Market-Space: A Strategic Perspective. Asian Journal of Business Management, 4(4): 359-366.

52. Zia M, and Manish A. (2012). Dissimilarity of E-marketing VS traditional marketing. International J. of Academic Research in Business and Social Sciences, 2(1), 511-515.

Citation: Gazi MAI. (2020). E-marketing practice in Bangladesh: an empirical study on trend of use and expansion in business, Can. J. Bus. Inf. Stud., 2(1), 12-23. https://doi.org/10.34104/cjbis.020.012023 (c) 